\title{
Effects of Guanidionoacetic Acid and Arginine Supplementation to Vegetable Diets Fed to Broiler Chickens Subjected to Heat Stress before Slaughter
}

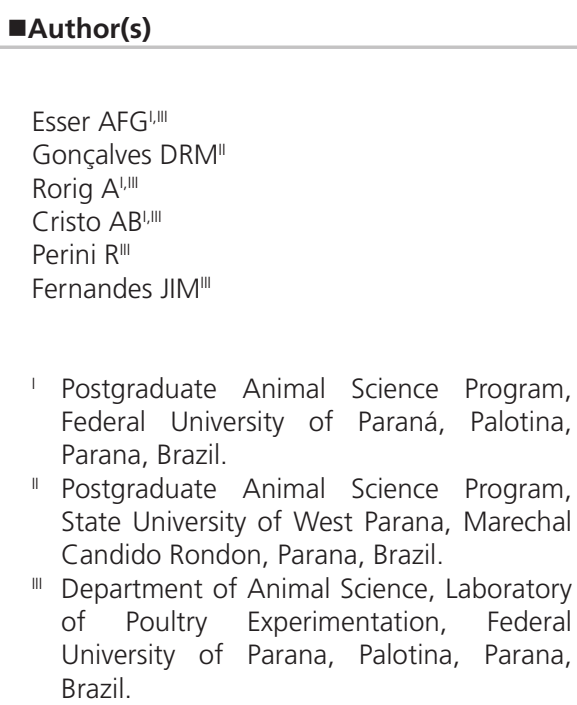

\section{Mail Address}

Corresponding author e-mail address Jovanir Inês Müller Fernandes

Federal University of Paraná, Palotina, Rua Pioneiro, 2153 - Paraná, Brazil, Zip code: 85950-000

Tel: $\quad+554432118525$

Email: jimfernandes@ufpr.br

\section{- Keywords}

Abdominal fat, creatine, meat quality, nitric oxide.

\section{ABSTRACT}

The objective of this study was to evaluate the supplementation of guanidinoacetic acid (GAA) and L-arginine (L-Arg) as creatine precursors to vegetable diets on the carcass yield and meat quality of broilers subjected to two days of heat stress before slaughter. A total of 1260 broiler chicks were distributed according to a completely randomized design into four treatments with nine replicates of 35 birds each. The treatments consisted of: T1 - vegetable diet based on corn and soybean meal (control diet); T2 - control diet with the inclusion of meat meal (3\%); T3 - control diet supplemented with GAA $(0.08 \%)$; and T4 - control diet supplemented with L-Arg (0.8\%). The birds were submitted to heat stress for two days before slaughter (from 42 to 44 days of age). The birds fed the diets supplemented with GAA or L-Arg presented heavier carcasses $(p<0.0035)$, higher breast yield $(p=0.0685)$, and lower of abdominal fat deposition $(p=0.0508)$ than those fed the control diet and the control diet with meat meal. The cooking loss of the breast fillets of broilers fed the control diet supplemented with meat meal, GAA or L-Arg was lower $(p<0.0068)$ compared with those fed the control diet. Thawing and pressure-driven breast fillet weight losses, and $\mathrm{pH}$, luminosity, redness ( $a^{*}$ value), and yellowness ( $b^{*}$ value) values were not influenced by the treatments. When GAA is less expensive than commercially-available Arg, the dietary supplementation of GAA is more advantageous, based on the meat yield improvements observed in the present study.

\section{INTRODUCTION}

Arginine (Arg) interacts with methionine (Met) in the creatine biosynthetic pathway (Smith, 1968). Arg transfers a guanidine group to glycine by the action of amidinotransferase, yielding ornithine and guanidinoacetic acid (GAA). In a second reaction catalyzed by guanidinoacetate, $\mathrm{N}$-methyltransferase GAA is methylated by S-adenosylmethionine to form S-adenosylhomocysteine and creatine (Block \& Schoenheimer, 1941; Borsook \& Dubnoff, 1945). Creatine can be stored in muscles or converted into creatinine, and both are excreted through the kidneys, resulting in the release of methyl groups.

Creatine plays a very important role in the energy transfer and replacement of adenosine triphosphate (ATP) reserves in muscle cells. It is used to feed the contraction process when combined with phosphate, being converted into phosphocreatine, which is essential for producing quick short energy bursts (Cain \& Davies, 1962).The initial fuel used for muscle contraction is ATP, which supplies energy by releasing one of its phosphate molecules, and being converted into adenosine diphosphate (ADP) (Febbraio et al., 1995). However, this system supplies energy for only a few seconds, after which new ATP molecules need to be produced. Creatine phosphate participates in cell 
energy supply by donating a phosphate molecule to ADP to restore ATP (Febbraio et al., 1995).

However, under heat stress, this metabolic pathway is changed. Chamruspollert (2001) verified that, when broilers were submitted to heat stress, creatine and creatinine levels were reduced in the excreta but did not increase in the muscle, indicating that heat-stressed broilers have low creatine biosynthesis (GonzalezEsquerra \& Leeson, 2006).

When the birds are submitted to high environment temperatures, Arg may be utilized for nitric oxide (NO) synthesis (Förstermann et al., 1991). Nitric oxide is an important signaling molecule, which stimulates vasodilation and reduces vascular resistance (Dimmeler \& Zeiher, 1999). It also plays an important role in glucose transport into the muscle during muscular contraction (Balon \& Nadler, 1997; Roberts et al., 1999). Therefore, broiler chickens kept under high environmental temperature may have increased Arg requirement for NO synthesis, and, in these situations, Arg can be key metabolism facilitator (Roberts et al., 1999; Cartee et al., 1989; Ruiz-Feria et al., 2001).

In addition, under heat stress, broiler rectal temperature and respiratory rate increase, consequently increasing the utilization of muscle energy reserves, which consist mostly of glycogen (Silva et al., 2001; Macari et al., 2004). Muscle energy reserves at the time of slaughter are highly influenced by transport duration and conditions to the processing plant and by the stress experienced by the birds before and during slaughter, which may cause glycogen depletion, negatively affecting meat functional properties.

The guanidinoacetic acid (GAA) is a biological precursor of creatine, and it is commercially available as a feed additive. It is effective than Arg or creatine supplementation because it is less expensive and chemically more stable than creatine. Furthermore, GAA also saves Arg and Gly for other metabolic pathways.

In this context, the evaluation of the dietary supplementation of GAA or Arg for broilers subjected to high environmental temperature during the preslaughter period, which is very frequent in tropical countries, may contribute for a better understanding of the role of creatine metabolism in muscle energy reserve and its relationship with the functional properties of broiler meat.

The objective of this study was to evaluate the supplementation of guanidinoacetic acid (GAA) and L-arginine (Arg) as creatine precursors to a vegetable diet of on the carcass yield and meat quality of broilers subjected to heat stress before slaughter.

\section{MATERIAL AND METHODS}

The experiment was conducted at the experimental poultry farm of the Federal University of Paraná, Palotina, state of Paraná, Brazil. All animal management and biological material collection procedures were approved by the Ethics Committee on Animal Use in Experimentation under protocol n. 12/2013 CEUA/ Palotina.

A total of 1260 male broiler chicks were used. Oneday-old broiler chicks were obtained from 40-weekold broiler breeders. The chicks were distributed according to a completely randomized design into four treatments with nine replicates of 35 birds each. The treatments consisted of:

T1 - vegetable control diet based on corn and soybean meal

T2 - vegetable control diet based on soybean meal and with inclusion of meat meal (3\%)

T3 - vegetable diet based on corn and soybean meal and supplemented with GAA $(0.08 \%)$

T4 - vegetable diet based on corn and soybean meal supplemented with L-Arg (0.8\%)

The commercial sources of GAA and Arg used were CreAMINOß (96\% guanidinoacetic acid; Evonik Degussa) and L-Arginine (99\% Arginine; Ajinomoto), respectively. The diets (Table 1) were formulated to supply the birds' nutritional requirements recommended by Rostagno et al. (2011), according to a 3-phase feeding program: starter diet (1 to 21 days), grower (22 to 37 days), and finisher (38 to 42 days) diets. Feed and water were supplied ad libitum during the entire experimental period.

On day 44, broiler house temperature was increased to $32^{\circ} \mathrm{C}$ and fan speed was decreased to $1.5 \mathrm{~m} / \mathrm{sec}$ for 48 hours. Air velocity has an important influence on body heat loss. Ventilation flow in the building affects heat, moisture, and gas balance, and therefore, building temperature, relative humidity, and gas concentration.

On 44 days, blood samples were collected from 12 birds per treatment for the determination of serum concentrations of uric acid, urea, creatine, lactate, and glucose. Serum samples kept frozen until biochemical analyses, which were conducted in the chemical analyzer BS-200 Mindray ${ }^{\circledR}$ (Mindray Medical International Limited) using DIALAB commercial kits, according to David et al. (1999).

After blood collection, the same birds were slaughtered by electrical stunning and further bleeding and then subjected to scalding, defeathering, and evisceration. Carcass yield was calculated as hot 
Table 1 - Nutritional composition of experimental diets: starter (from 1 to 21 days of age), grower (from 22 to 37 days of age) and finisher (from 38 to 44 days of age)

\begin{tabular}{|c|c|c|c|c|c|c|}
\hline \multirow[t]{2}{*}{ Ingredients, kg } & \multicolumn{2}{|c|}{ Starter } & \multicolumn{2}{|c|}{ Grower } & \multicolumn{2}{|c|}{ Finisher } \\
\hline & $\mathrm{T} 2$ & $\mathrm{~T} 1, \mathrm{~T} 3, \mathrm{~T} 4$ & $\mathrm{~T} 2$ & $\mathrm{~T} 1, \mathrm{~T} 3, \mathrm{~T} 4$ & $\mathrm{~T} 2$ & T1, T3 T4 \\
\hline Corn & 62.20 & 60.30 & 65.08 & 62.64 & 67.76 & 65.13 \\
\hline Soybean meal (46\%) & 32.40 & 35.20 & 27.60 & 30.80 & 18.13 & 17.07 \\
\hline Micronized soybeans & - & - & - & - & 9.33 & 14.67 \\
\hline Soybean oil & - & 0.8 & 2.2 & 3.10 & - & - \\
\hline Meat meal (45\%) & 3.0 & - & 3.0 & - & 3.0 & - \\
\hline Sodium chloride & 0.300 & 0.340 & 0.280 & 0.320 & 0.320 & 0.373 \\
\hline Inert material ${ }^{1}$ & 0.100 & 0.100 & 0.100 & 0.100 & 0.100 & 0.100 \\
\hline Limestone & 0.560 & 0.940 & 0.460 & 0.940 & 0.480 & 0.907 \\
\hline Dicalcium phosphate & 0.140 & 1.060 & 0.080 & 0.900 & - & 0.853 \\
\hline Sodium bicarbonate & 0.100 & 0.100 & 0.100 & 0.100 & - & - \\
\hline DL-Met 98\% & 0.284 & 0.279 & 0.191 & 0.183 & 0.192 & 0.189 \\
\hline L-Lysine $50.7 \%$ & 0.385 & 0.358 & 0.418 & 0.372 & 0.360 & 0.333 \\
\hline L-Threonine 98\% & 0.086 & 0.078 & 0.032 & 0.020 & 0.059 & 0.053 \\
\hline L-Tryptophan 98\% & - & - & 0.006 & - & - & - \\
\hline Choline chloride $60 \%$ & 0.042 & 0.040 & 0.045 & 0.042 & 0.031 & 0.025 \\
\hline Vit. e mineral premix $x^{2,3}$ & 0.400 & 0.400 & 0.400 & 0.400 & 0.300 & 0.300 \\
\hline \multicolumn{7}{|l|}{ Calculated values } \\
\hline Crude protein, \% & 21.67 & 21.43 & 19.64 & 19.51 & 18.66 & 18.44 \\
\hline ME (kcal/kg) & 2950 & 2950 & 3130 & 3130 & 3153 & 3153 \\
\hline Calcium & 0.881 & 0.850 & 0.817 & 0.821 & 0.800 & 0.786 \\
\hline Available Phosphorus & 0.439 & 0.442 & 0.420 & 0.419 & 0.400 & 0.395 \\
\hline Dig. Lysine, \% & 1.199 & 1.201 & 1.100 & 1.101 & 1.001 & 0.999 \\
\hline Dig. Met+Cys, \% & 0.864 & 0.864 & 0.727 & 0.727 & 0.701 & 0.700 \\
\hline Dig. Threonine, \% & 0.780 & 0.780 & 0.660 & 0.660 & 0.648 & 0.648 \\
\hline Dig. Tryptophan, \% & 0.222 & 0.230 & 0.203 & 0.208 & 0.182 & 0.190 \\
\hline Dig. Leucine, \% & 1.636 & 1.643 & 1.510 & 1.525 & 1.435 & 1.432 \\
\hline Dig. Isoleucine, \% & 0.824 & 0.843 & 0.737 & 0.763 & 0.678 & 0.690 \\
\hline Dig. Valine, \% & 0.902 & 0.904 & 0.816 & 0.825 & 0.758 & 0.753 \\
\hline Dig. Arginine, \% & 1.296 & 1.297 & 1.158 & 1.159 & 1.080 & 1.080 \\
\hline $\mathrm{Na}+\mathrm{K}-\mathrm{Cl}$, meq $/ \mathrm{kg}$ & 236 & 241 & 212 & 219 & 194 & 202 \\
\hline
\end{tabular}

'Inert material: replaced by GAA and L-Arg

${ }_{2}^{2}$ Starter and grower premix (content per kg of premix): Folic acid 625.00mg; Pantothenic acid 4500.00mg; Amylase 50000.00U, Zinc bacitracin 13.75g; Biotin 50.00mg; Copper 2000.00mg; Ethoxyquin 16.65g; Iron 17.50g; Phytase 125000.00U; lodine 250.00mg, Manganese 30.00g; Niacin 10.00g; Protease 1000000.00U; Selenium 60.00mg; Vitamin A 3000000.00Ul; Vitamin B1 750.00mg; Vitamin B12 5000.00mg; Vitamin B2 2000.0mg; Vitamin B6 1250.00mg; Vitamin D3 875000.00IU; Vitamin E 7500.00IU; Vitamin K3 750.00 mg; Xylanase 500000.00U; Zinc 25.00g.

${ }^{3}$ Finisher premix (content per kg of premix): Folic acid 333.40mg; Pantothenic acid 4000.00mg; Amylase 66668.00U; Biotin 66.67mg; Copper 2667.00mg; Iron 20.00g; Phytase 166570.00U; Butylatedhydroxytoluene 33.33g; lodine 334.00mg, Manganese 33.33g; Niacin 10.00g; Protease 1333360.00U; Selenium 80.00mg; Vitamin A 2333333.30IU; Vitamin B1 500.00 mg; Vitamin B12 4000.00 mg; Vitamin B2 1567.00 mg; Vitamin B6 1187.00mg; Vitamin D3 833989.00lU; Vitamin E 5657.00lU; Vitamin K3 1000.00 mg; Xylanase 565580.00U; Zinc 25.57g.

eviscerated carcass (without feet, head and abdominal fat pad) weight relative to body weight obtained measured before slaughter in individual birds. In order to determine prime cuts yield, which included the entire breast with skin and bones, the breast fractions fillet and sassami, and the legs (drumstick and thighs with bones and skin) of individual birds were weighed, and their yields were calculated as a percentage of hot eviscerated carcass weight. Abdominal fat around the cloaca, cloacal bursa, gizzard, proventriculus, and adjacent abdominal muscles was removed as described by Smith (1993), weighed and calculated relative to eviscerated carcass weight.
The right pectoralis major muscle of each bird was identified and kept at room temperature for 15 minutes post-mortem for $\mathrm{pH}$ measurement by the direct introduction of a glass electrode in the apical region of the muscle. The measurements were taken at 1 hour (initial $\mathrm{pH}$ ) and 24 hours (ultimate $\mathrm{pH}$ ) after slaughter under a $0 \pm 2^{\circ} \mathrm{C}$ refrigeration, one reading at each time.

Color measurements on the ventral side of the same fillet samples were performed 24 hours post mortem, on three different reading points per sample. Color was measured using a Minolta CR 10 colorimeter. The color values $L^{*}$ (luminosity), $a^{*}$ (redness index) and $b$ * 
(yellowness index) were expressed according to the CIELAB color system.

Pressure-driven water loss was determined in 2-g portion of the right breast muscle sample on a semianalytical balance. The sample was placed between two paper filters (Whatman n.1) and pressed between two acrylic plates to which a 10-kg weight was applied for five minutes. After pressing, the sample was weighed again, and pressure-driven water loss was calculated as the weight difference before and after pressure.

The fresh left pectoralis major muscle was weighed and then cooked in a preheated electric oven at $180^{\circ} \mathrm{C}$ for about 5 min on each side until its internal temperature reached $72^{\circ} \mathrm{C}$. The cooked muscles were stored at $4 \pm 2^{\circ} \mathrm{C}$ for 12 hours and then weighted again in order to calculate cooking loss as the difference between fresh and cooked weigh.

The fresh left pectoralis minor muscle was weighed and frozen, and then thawedat $4 \pm 2^{\circ} \mathrm{C}$ for 24 hours to determine thawing weight loss.

For statistical analysis, data were verified for the presence of outliers, and tested for normality of studentized errors (Cramer-Von Mises test) and homogeneity of variance (Brown-Forsythe's test). After these assumptions were satisfied, data were submitted to analysis of variance using the' GLM procedure of SAS statistical software (SAS Institute, 2002). When significant differences were detected, means were compared by the test of Tukey.

\section{RESULTS AND DISCUSSION}

Table 2 shows the serum biochemistry results of the birds fed the experimental diets. There was no significant effect $(p>0.05)$ of the dietary supplementation of meat meal, GAA, or L-Arg on the serumuric acid, urea, creatine, lactate, or glucose levels of the heat-stressed broilers. The intensity of thermal discomfort possibly was not sufficient to cause changes in the analyzed metabolites, assuming metabolic homeostasis and maximum utilization of dietary nutrients.
Blood glucose levels considered normal for broilers range between 200 and $500 \mathrm{mg} / \mathrm{dL}$ (Campbell, 2004). During the acute period of heat stress, blood glucose level is maintained by glycogenolysis from lactate (Hocquette et al., 1998). Therefore, the blood concentration of lactate relies on its production and degradation in the liver, kidneys, and skeletal muscles (Henry, 2008). The measurement of plasma lactate has been widely used for the evaluation of stress, meat quality and control of animal welfare in pigs (Ludtke et al., 2010; Baptista et al., 2011).

Serum creatine levels were stable regardless of dietary GAA and L-Arg supplementation. Creatine and phosphocreatine are not present in all cells, but only in high-energy expenditure cells, particularly in muscle cells. This system works as a ADP-ATP cycle backup in order to store and mobilize energy when necessary in the short term (Michiels et al., 2012).

The increase in urea levels is associated with the degradation of Arg to ornithine. About 40 to $60 \%$ of the urea circulating in birds is the result of ornithine synthesis (Ruiz-Faria et al., 2001). Arginine transfers a guanidino group to glycine, forming ornithine and guanidinoacetate. In a second reaction catalyzed by guanidinoacetate $\mathrm{N}$-methyltransferase, GAA is methylated by S-adenosylmethionineto form S-adenosylhomocysteine and creatine (Block \& Schoenheimer, 1941). Therefore, altered urea levels were expected with the dietary supplementation of GAA in the present study. A hypothesis which may explain the absence of effects of the experimental diets on urea levels is that the dietary Arg levels met the broilers' requirements for all Arg metabolic pathways (protein synthesis, ornithine, polyamines, proline, creatine, proteins synthesis, nitric oxide, and citrulline).

The results of carcass and commercial cuts yields is shown in Tables 3 (absolute weights) and 4 (relative weights). There was a significant effect $(p<0.05)$ of the dietary addition of GAA and Arg on carcass weight, which was 3.20\% higher compared with the control diet and that with meat meal inclusion. There was

Table 2 - Serum concentration of uric acid, creatine, glucose, lactate and urea in 44-day-old broilers fed vegetable diets with meat meal, GAA, or L-Arg and submitted to pre-slaughter heat stress.

\begin{tabular}{|c|c|c|c|c|c|}
\hline Diets & $\begin{array}{c}\text { Uric Acid, } \\
\mathrm{mg} / \mathrm{dL}\end{array}$ & $\begin{array}{c}\text { Creatine } \\
\mathrm{mg} / \mathrm{dL}\end{array}$ & $\begin{array}{l}\text { Glucose } \\
\mathrm{mg} / \mathrm{dL}\end{array}$ & $\begin{array}{l}\text { Lactate } \\
\mathrm{mg} / \mathrm{dL}\end{array}$ & $\begin{array}{l}\text { Urea, } \\
\mathrm{mg} / \mathrm{dL}\end{array}$ \\
\hline Vegetable diet & 3.00 & 0.20 & 267.58 & 4.91 & 4.79 \\
\hline Vegetable diet + meat meal & 2.87 & 0.19 & 272.19 & 4.99 & 4.72 \\
\hline Vegetable diet + GAA & 2.83 & 0.20 & 265.16 & 4.85 & 5.08 \\
\hline Vegetable diet + L-Arg & 2.81 & 0.21 & 252.02 & 5.34 & 4.31 \\
\hline$C V, \%$ & 25.41 & 34.59 & 5.82 & 16.25 & 33.23 \\
\hline$p$ value & 0.3955 & 0.9699 & 0.6195 & 0.9117 & 0.6036 \\
\hline
\end{tabular}


Table 3 - Carcass, prime cuts and abdominal fat weight (g) of 44-day-old broilers fed vegetable diets with meat meal, GAA, or L-Arg and submitted to pre-slaughter heat stress.

\begin{tabular}{lcccccc}
\hline Diets & Carcass & Breast & Legs & Fillet & Sassami & Fat \\
\hline Vegetable diet & $2492.17^{\mathrm{b}}$ & 827.33 & 680.33 & 291.66 & 60.53 & 60.90 \\
Vegetable diet + meat meal & $2492.25^{\mathrm{b}}$ & 871.17 & 655.33 & 309.00 & 63.44 & 62.85 \\
Vegetable diet + GAA & $2571.83^{\mathrm{a}}$ & 844.80 & 691.67 & 298.40 & 63.53 & 52.64 \\
Vegetable diet + L-Arg & $2508.00^{\mathrm{a}}$ & 856.64 & 673.83 & 292.00 & 60.42 & 55.11 \\
CV, $\%$ & 6.06 & 7.23 & 7.15 & 7.81 & 12.79 & 24.89 \\
$p$ value & 0.0335 & 0.3658 & 0.3252 & 0.2536 & 0.6332 & 0.2774 \\
\hline
\end{tabular}

Table 4 - Carcass, commercial cuts and abdominal fat yield (\%) of 44-day-old broilers age fed vegetable diets with meat meal, GAA, or L-Arg and submitted to pre-slaughter heat stress.

\begin{tabular}{|c|c|c|c|c|c|c|}
\hline & Carcass & Legs & Breast & Filet & Sassami & Fat \\
\hline Vegetable diet & 76.24 & 27.30 & $33.21^{\mathrm{b}}$ & 11.73 & 2.433 & $2.75^{a}$ \\
\hline Vegetable diet + meat meal & 76.10 & 26.29 & $34.93^{a}$ & 12.42 & 2.552 & 2. $95^{\mathrm{a}}$ \\
\hline Vegetable diet + GAA & 76.61 & 26.90 & $34.04^{a}$ & 11.62 & 2.484 & 1. $83^{\mathrm{b}}$ \\
\hline Vegetable diet + L-Arg & 77.12 & 26.59 & $34.81^{a}$ & 11.98 & 2.408 & 2. $25^{b}$ \\
\hline$C V, \%$ & 1.60 & 3.97 & 5.06 & 9.12 & 13.41 & 5. 603 \\
\hline$p$ value & 0.1921 & 0.1348 & 0.0685 & 0.3160 & 0.7235 & 0.0508 \\
\hline
\end{tabular}

also greater breast yield ( $p=0.0685)$ when the heatstressed birds were fed diets supplemented with meat meal, GAA and L-Arg compared with the control diet, and lower abdominal fat deposition $(p=0.0508)$ was observed in broilers fed diets supplemented with GAA or L-Arg.

Creatine plays a critical role in energy metabolism, and it is the only organic compound that is involved in protein metabolism and that participates in the muscular energy buffering system (Khajali \& Wideman, 2010; Chen et al., 2011). Michiels et al. (2012) reported that a diet supplemented with GAA $(0.6$ and $1.2 \mathrm{~g} / \mathrm{kg})$ markedly increased the creatine concentration in broiler breast meat. In this sense, GAA supplementation can be particularly important in diets for broiler strains with fast initial growth due to their high energy requirements to supply muscle creatine (Brosnan et al., 2009).

Another mode of action of GAA is associated with amino acid metabolism. In vivo, GAA is synthesized from glycine and arginine, and consequently, GAA supplementation may spare arginine, one of the potentially limiting amino acids in low-protein broiler diets (Baker, 2009; Dilger et al., 2013).

Ojano-Dirain \& Waldroup (2002) and Akit et al. (2005) reported that high poultry house temperature has a negative effect on carcass composition and meat yield. Those authors report that the main effects observed are the reduction of carcass protein accretion and increase in abdominal fat deposition. In the present experiment, the dietary supplementation with GAA or L-Arg may have contributed to creatine synthesis and the maintenance of protein accretion despite the adverse temperature conditions.

The positive effect of Arg in reducing abdominal fat deposition in broilers was also observed by Mendes et al. (1997) and Costa et al. (2001). In particular, AlDaraji et al. (2011) observed a significant reduction in abdominal fat percentage and a significant improvement in carcass, breast muscle and leg yields of 42-d-old quails fed diets supplemented with Arg. Dietary L-Arg supplementation may reduce fat deposition by modulating lipogenesis, by reducing the expression of lipogenic genes or increasing the expression of genes associated with lipolysis (Corzo et al., 2003; Wu et al., 2011).

Another hypothesis that may explain this action of Arg is based on the study of Sun et al. (2006), who found a negative correlation between IGF-I serum levels and body fat percentage of broiler breeders fed ad libitum. Arginine demonstrably stimulates growth hormone and insulin-like growth factor (IGF) secretion. McMurtry (1998), in a review about the action of growth factors involved in the postnatal development of poultry, also showed that the decrease of abdominal fat is associated with enhanced IGF-I plasma levels, and that the IGF system may be more related to the intermediary metabolism than to the growth of broilers perse.

The results of meat cooking, thawing, and pressuredriven weight losses (Table 5 ) show a significantly lower $(p<0.05)$ cooking loss of the breast fillets of broilers fed the diet supplemented with meat meal compared with the control diet. Michiels et al. (2012) found that 
Table 5 - Meat cooking, thawing, and pressure-driven losses of the breast fillets of 44-day-old broilers fed diets with meat meal, GAA, or L-Arg submitted to pre-slaughter heat stress.

\begin{tabular}{lccc}
\hline \multirow{2}{*}{ Diets } & & Losses (\%) & \\
\cline { 2 - 4 } & Cooking & Thawing & Pressure-driven \\
\hline Vegetable diet & $28.43^{\mathrm{a}}$ & 3.56 & 8.45 \\
Vegetable diet + meat meal & $24.94^{\mathrm{b}}$ & 3.26 & 8.46 \\
Vegetable diet + GAA & $26.64^{\mathrm{ab}}$ & 2.93 & 8.38 \\
Vegetable diet + L-Arg & $26.03^{\mathrm{ab}}$ & 3.40 & 10.54 \\
CV, $\%$ & 7.72 & 34.48 & 27.26 \\
$p$ value & 0.0068 & 0.8418 & 0.0960 \\
\hline
\end{tabular}

the pressure-driven and cooking losses of the meat of broilers fed a vegetable diet supplemented with GAA were higher compared with those obtained with the vegetable diet with no GAA, but were not different from those observed with a carnivore diet. Heat stress may increase muscle creatine kinase activity, change cell membrane integrity in the glycolytic metabolism of the breast muscle, and increase the osmotic effect of the membrane (Wang et al., 2009).

Luminosity, redness, yellowness, and $\mathrm{pH}$ results obtained in the breast fillets are shown in Table 6 . There was no significant effect $(p>0.05)$ of the experimental diets on these characteristics, despite significant difference observed in cooking loss. Chicken meat with lower ultimate $\mathrm{pH}$ values has lower water holding capacity, which influences cooking loss and drip loss, while higher ultimate $\mathrm{pH}$ values often indicate higher meat tenderness (Barbut, 1993) and longer shelf life. Muscle glycogen levels at the time of death largely determines ultimate $\mathrm{pH}$ (Zhu et al, 2011). After slaughter, the muscle converts glycogen into energy and lactate, which reduces its $\mathrm{pH}$. Muscles with the same lactate concentration may have a different ultimate $\mathrm{pH}$ values (Van Laack et al., 2000); however, the reasons are not clear. These differences may result from complex interactions between the genotype and the environment, and particularly from the stresses experienced before slaughter. Heat-stressed birds use their glycogen reserves faster than non-stressed birds, which may result in the depletion of glycogen in vivo. In the present study, the ultimate $\mathrm{pH}$ value of all samples was below 5.8, and the color was lighter than normal $\left(L^{*}>52\right)$, which may indicate the presence of the PSE (pale, soft, and exudative) chicken meat defect (Bressan et al., 2002).

Creatine is an alkaline substance, and its presence may limit $\mathrm{pH}$ decline. On the other hand, ante-mortem stress reduces the level of creatine phosphate in the muscle at the time of slaughter, possibly leading to lower ultimate $\mathrm{pH}$ for the same level of lactate. However, GAA supplementation does not prevent the $\mathrm{pH}$ decline of meat heat-stressed birds (Van Laack et al., 2000). Tossenberger et al. (2016) supplemented broiler chickens' diets with GAA and showed a gradual increase in muscle creatine values. One hour postmortem, the muscle ATP value of GAA-fed birds was significantly higher compared to those who did not receive GAA, probably due to an improvement in cell energy metabolism.

The lack of more meaningful results obtained with the supplementation of Arg and GAA in the diet of broilers subjected to heat stress may be attributed to the high levels of digestible Arg in the control diets, of $1.296,1.158$ and $1.159 \%$ in the starter, grower, and finisher diets respectively. Therefore, these Arg levels were probably sufficient for the Arg-NO and Arg-creatine cycles, despite the situation of heat stress. Apparently, the dietary supplementation with Arg in situations of heat stress has positive results due to the three interrelated and interdependent mechanisms that are simultaneously triggered by vasodilation and increased blood perfusion (Meneilly et al., 2001),

Table 6 - Lightness $\left(L^{*}\right)$, redness $(a *)$, yellowness $\left(b^{*}\right)$, and $p H$ values of the breast fillets of 44 -day-old broilers fed diets with meat meal, GAA, or L-Arg and submitted to pre-slaughter heat stress.

\begin{tabular}{|c|c|c|c|c|c|}
\hline \multirow{2}{*}{ Diets } & \multicolumn{3}{|c|}{ Color } & \multicolumn{2}{|c|}{$\mathrm{pH}$} \\
\hline & $L^{*}$ & $a^{*}$ & $b^{*}$ & Initial & Ultimate \\
\hline Vegetable diet & 52.64 & 3.15 & 6.43 & 6.16 & 5.37 \\
\hline Vegetable diet + meat meal & 52.13 & 3.31 & 7.47 & 6.11 & 5.40 \\
\hline Vegetable diet + GAA & 53.47 & 2.32 & 7.31 & 6.27 & 5.34 \\
\hline Vegetable diet + L-Arg & 52.81 & 3.05 & 6.22 & 6.25 & 5.39 \\
\hline$C V, \%$ & 7.02 & 40.16 & 24.8 & 3.08 & 3.78 \\
\hline$p$ value & 0.6650 & 0.1949 & 0.1995 & 0.3083 & 0.9022 \\
\hline
\end{tabular}


Esser AFG, Gonçalves DRM, Rorig A, Cristo $A B$, Perini $R$, Fernandes JIM
Effects of Guanidionoacetic Acid and Arginine Supplementation to Vegetable Diets Fed to Broiler Chickens Subjected to Heat Stress before Slaughter which facilitate the intake of oxygen and nutrients by the tissues. The increased supply of glucose for muscle activity provides more energy substrate for muscle contraction and reduces ammonia and lactate blood concentrations (Schaefer et al., 2002).

Schaefer et al. (2002) also states that Arg supplementation favors the Arg-NO mechanism triggered by exercise, increasing the formation of NO from Arg, increasing vasodilation and consequently muscle perfusion. Thus, the supplementation of GAA may save Arg for this function, and serve as substrate for the formation of muscle creatine, essential for the maintenance of muscle energy.

\section{CONCLUSION}

We conclude that the supplementation of vegetable diets with L-Arg or GAA did not change the serum biochemistry or the meat quality of broilers subjected to heat stress. However, the supplementation of vegetable diets with Arg or GAA resulted in higher carcass weight and breast yield, as well as lower abdominal fat deposition in broilers subjected to heat stress. When GAA is less expensive than commerciallyavailable Arg, the dietary supplementation of GAA is more advantageous, based on the meat yield improvements observed in the present study.

\section{REFERENCES}

Akit M, Yalcin S, Ozkan S, Metin K, Ozdemin D. Effects of temperature during rearing and crating on stress parameters and meat quality of broilers. Poultry Science 2005;85(11):1867-1874.

Al-Daraji HJ, Al-Mashadani AA, Al-Hayani WK, Al-Hassani AS, Mirza $H A$. Influence of in ovo injection of L-arginine on productive and physiological performance of quails. Research Opinions in Animal \& Veterinary Sciences 2011;1(7):463-467.

Baker $\mathrm{DH}$. Advances in protein-amino acid nutrition of poultry. Amino Acids 2009;37(1):29-41.

Balnave D, Brake J. Responses of broilers to sodium bicarbonate supplementation of diets containing varying arginine: Lysine ratios. Australian Journal of Agricultural Research 1999;50(3):425-430.

Balon TW, Nadler JL. Evidence that oxide nitric increases glucose transport in skeletal muscle. Jounal of Applied Physiology 1997;82(1):359-363.

Baptista RIAA, Bertani GR, Barbosa CN. Indicadores do bem-estar em suínos. Ciência Rural 2011;41(10):1823-1830.

Barbut S. Colour measurements for evaluating the pale, soft, exudative [PSE] occurrence in turkey meat. Food Research International 1993;26(1):3943.

Bianchi M, Bianchi M, Petracci M, Sirri F, Folegatti E, Franchini A, et al. The influence of the season and Market class of broiler chickens. Poultry Science 2007;86(5):959-963.

Block K, Schoenheimer R. The biological precursors of creatine. The Journal of Biological Chemistry 1941;138(1):167-194.
Borsook H, Dubnoff JW. Methylation of guanidoacetic acid by homocystine plus choline with rat liver slices. Journal of Biological Chemistry 1945;160(2):635-636.

Bressan MC, Beraquet NJ. Effect of pre-slaughter factors on the quality of chicken breast meat. Ciência e Agrotecnologia 2002;26(5):1049-1059.

Cain DF, Davies RE. Breakdown of adenosine triphosphate during a single contraction of working muscle. Biochemical and Biophysical Research Communications 1962;8:361-366.

Campbell TW. Clinical Chemistry of Birds. In: Thrall MA, editor. Veterinary hematology and clinical chemistry. Philadelphia: Lippincott, Williams \& Wilkins; 2004. p. 479-492.

Cartee GD, Young DA, Sleeper MD, Zierath J, Wallberg-Henriksson $\mathrm{H}$, Holloszy JO. Prolonged increase in insulin stimulated glucose transport in muscle after exercise. The American Journal of Physiology 1989;256(4):494-499.

Chamruspollert M. Interrelationships between dietary arginine, methionine, and environmental temperature affect growth and creatine biosynthesis in young broiler chicks [dissertation]. Athens (GA): University of Georgia; 2001.

Chen J, Wang M, Kong $\mathrm{Y}, \mathrm{Ma} \mathrm{H}$, Zou S. Comparison of the novel compounds creatine and pyruvate on lipid and protein metabolism in broiler chickens. Animal: an international Journal of Animal Bioscience 2011;5(7):1082-1089.

Corzo A, Moran ETJR, Hoehler D. Arginine need of heavy broiler males: applying the; deal protein concept. Poultry Science 2003;82(3):402407.

Costa FGP, Rostagno HS, Toledo RS, Albino LFT. Effect on the performance and carcass quality of broiler 3 to 6 weeks of age under high temperature conditions. Revista Brasileira de Zootecnia 2001;30(6):2021-2025.

David B, Sacks MB, ChB FACP. Carbohydrates. In: Burtis CA, Ashwood $E R$, editors. Tietz text book of clinical chemistry. Philadelphia: W.B. Saunders; 1999. p.787-790.

Dilger RN, Bryant-Angeoni Payne K, Lemme A. Parsons CM. Dietary guanidino acetic acid is an efficacious replacement for arginine for young chicks. Poultry Science 2013;92(1):171- 177.

Dimmeler S, Zeiher AM. Nitric oxide-an endothelial cell survival factor. Cell Death and Differentiation 1999;6(10):964-968.

Febbraio M, Flanagan T, Snow R. Effect of creatine supplementation on intramuscular $\mathrm{TCr}$, metabolism and performance during intermittent, supramaximal exercise in humans. Acta Physiologica Scandinavica1995;155(4):387-395.

Förstermann U, Schmidt HHH, Pollock JS, Sheng H, Mitchell JA, Warner TD, et al. Isoforms of nitric oxide synthase: characterization and purificalion from different cell types. Biochemical Pharmacology 1991;42(10):18491857.

Gonzalez-Esquerra R, Leeson S. Concentrations of putrescine, spermidine, and spermine in duodenum and pancreas as affected by the ratio of arginine to lysine and source of methionine in broilers under heat stress. Poultry Science 2006;85(8):1398-1408.

Henry JB. Clinical treatment and diagnostic laboratory methods. 20th ed. São Paulo: Manole; 2008.

Hocquette JF, Ortigues-Marty I, Pethick D. Nutritional and hormonal regulation of energy metabolism in skeletal muscles of meat-producing animals. Livestock Production Science 1998;56(2):115-143.

Khajali F, Wideman RF. Dietary arginine: metabolic, environmental, immunological and physiological interrelationships. World's Poultry Science Journal 2010;66(4):751-766. 
Esser AFG, Gonçalves DRM, Rorig A,

Cristo AB, Perini R, Fernandes JIM
Ludtke CB, Silveira ETF, Bertoloni W, Andrade JC, Buzelli ML, Bessa LR, et al. Well-being and quality of pigmeatun der differentpre slaughterhandling techniques. Revista Brasileira de Saúde e Produção Animal 2010;11(1): 231-241.

Macari M, Furlan RL, Maiorka A. Aspectos fisiológicos e de manejo para manutenção da homeostasetérmica e controle de síndromes metabólicas. In: Mendes AA, Nääs IA, Macari M, editores. Produção de frangos de corte. Campinas: FACTA; 2004. p.137-155.

Mcmurtry JP. Nutritional and developmental roles of insulin-like growth factors in poultry. The Journal of nutrition 1998;128(2):302-305.

Mendes AA, Watkins SE, England JA, Saleh EA, Waldroup AL, Waldroup PW. Influence of dietary lysine levels and arginine:lysine ratios on performance of broilers exposed to heat or cold stress during the period of three to six weeks of age. Poultry Science 1997;6(3):472-481.

Meneilly GS, Battistinl B, Floras JS. Contrasting effects of Larginine on insulin-mediated blood flow and glucose disposal in the elderly. Metabolism: Clinical and Experimental 2001;50(2):194-199.

Michiels J, Maertens L, Buyse J, Lemme A, Rademacher M, Dierick NA, De Smet S. Supplementation of guanidine acetic acid to broiler diets: Effects on performance, carcass characteristics, meat quality, and energy metabolism. Poultry Science 2012;91(2):402-412.

Ojano-Dirain CP, Waldroup PW. Protein and Amino Acid Needs of Broilers in Warm Weather: A Review. International Journal of Poultry Science 2002;1(4):40-46.

Roberts CK, Barnard RJ, Jasman A,Balon TW. Acute exercise increases nitric oxide synthase activity in skeletal muscle.The American journal of physiology 1999;277(2):390-394.

SAS - Statistical Analysis System. User's guide. Cary: SAS Institute; 2002.

Rostagno HS, Albino LFT, Donzele JL, Gomes PC, Oliveira RF, Lopes DC, et al. Tabelas brasileiras para aves e suínos (composição de alimentos e exigências nutricionais). Viçosa: Universidade Federal de Viçosa; 2011. $252 p$

Ruiz-Feria CA, Kidd MT, Widemann RF. Plasma levels of arginine, ornithine and urea and growth performance of broilers fed suplemental l-arginine during cool temperature exposure. Poultry Science 2001;80(3):358-69.
Schaefer A, Piquard F, Geny B, Doutreleau S, Lampert E, Mettauer B, et al. L-arginine reduces exercise-induced increase in plasma lactate and ammonia. International Journal of Sports Medicine 2002;23(6):403407.

Silva MAN, Silva IJO, Piedade SMS, Martins E, Coelho AAD, Savino VJM. Resistance to heat stress in naked neck broiler. Revista Brasileira de CiênciaAvícola 2001;3(1):27-33.

Smith MO. Parts yeld of broilers reared under cycling high temperatures. Poultry Science 1993;72(6):1146-1150.

Smith RE. Effect of arginine upon the toxicity of excesses of single amino

Sun JM, Richards MP, Rosebrough RW, Ashwell CM, McMurtry JP, Coon $\mathrm{CN}$. The relationship of body composition, feed Intake, and metabolic hormones for broiler breeder females. Poultry Science 2006;85(7):11731184

Tossenberger J, Rademacher M, N'emethK, Halas V, Lemme A. Digestibility and metabolism of dietary guanidino acetic acid fed to broilers. Poultry Science 2016;95(9):2058-2067.

Van Laack RL, Lane JL. Denaturation of myofibrillar proteins from chicken as affected by $\mathrm{pH}$, temperature, and adenosine triphosphate concentration. Poultry Science 2000;79(1):105-109.

Wang RR, Pan XJ, Peng ZQ. Effects of heat exposure on muscle oxidation and protein functionalities of pectoralis majors in broilers. Poultry Science 2009;88(5):1078-1084.

Williams MH, Kreider RB, Branch JD. Creatina. São Paulo: Manole; 2008.

Wu LY, Fang YJ,Guo XY. Dietary L-arginine supplementation beneficially regulates body fat deposition of meat-type ducks. British Poultry Science 2011;52(2):221-226.

Zhu X, Ruusunen M, Gusella M, Zhou G, Puolanne E. High post-mortem temperature combined with rapid glycolysis induces phosphorylase denaturation and produces pale and exudative characteristics in broiler Pectoralis major muscles. Meat Science 2011;89(2):181-188 acids in chicks. Journal of Nutrition 1968;95(4):547-553. 